\title{
Stimulation of transcription by an Ultrabithorax protein in vitro
}

\author{
F. Brad Johnson and Mark A. Krasnow ${ }^{1}$ \\ Department of Biochemistry, Stanford University, Stanford, California 94305 USA
}

\begin{abstract}
The Ultrabithorax (Ubx) gene of Drosophila melanogaster encodes a family of UBX proteins that are thought to specify the developmental fates of segments in the posterior thorax and anterior abdomen by controlling the expression of a set of target genes. UBX proteins bind DNA in vitro, and they activate or repress different natural and synthetic target promoters in cultured cells. Here it is shown that a purified UBX protein can stimulate transcription of a synthetic target gene in extracts of cultured $D$. melanogaster cells. Stimulation is dependent on the presence of upstream, promoter-region binding sites but is independent of binding site orientation. A naturally occurring binding site cluster and a binding site consensus sequence consisting of TAA trinucleotide repeats can mediate this activation. A minimal promoter fused to such sites is activated by UBX, suggesting that transcriptional stimulation could result from an interaction between the promoter-bound protein and the general transcriptional machinery.
\end{abstract}

[Key Words: Drosophila development; Ultrabithorax; transcriptional regulation; transcription factor; in vitro transcription; homeotic gene]

Received November 2, 1989; revised version accepted March 14, 1990.

The specialized form and function of the different body segments of Drosophila melanogaster are specified during development by homeotic genes such as Ultrabithorax $(U b x)$ and Antennapedia $(A n t p)$. Ubx selects segmental fates primarily in the posterior thorax and anterior abdomen (Lewis 1978; for review, see Duncan 1987), and Antp specifies segmental fates primarily in the anterior thorax (Wakimoto and Kaufman 1981; for review, see Kaufman et al. 1990). The homeotic genes constitute a key intermediate level of a regulatory hierarchy of 40 or more genes, in which early-acting genes involved in segmentation of the animal, such as fushi tarazu (ftz) and even-skipped (eve), ensure the regionspecific expression of $U b x, A n t p$, and other homeotic genes (for review, see Akam 1987; Scott and Carroll 1987; Ingham 1988). The initial patterns of expression of the homeotic genes are then refined by cross regulation and autoregulation. For example, $U b x$ products are required to repress Antp expression in the posterior thorax and anterior abdomen (Hafen et al. 1984; Carroll et al. 1986; Wirz et al. 1986), and they are also required for high-level $U b x$ expression in the visceral mesoderm (Bienz and Tremml 1988). It has been proposed that $U b x$ and other homeotic genes also control an as yet unidentified set of downstream genes that constitute the next level of the hierarchy and that elaborate the unique anatomy of different segments (Lewis 1964; Garcia-Bellido 1975|. A molecular understanding of homeotic gene function requires identifying downstream genes and de-

${ }^{1}$ Corresponding author. termining how homeotic gene products interface with other cellular components to control the expression of target genes.

$U b x$ functions are mediated by the UBX proteins, a family of $\sim 40-\mathrm{kD}$ proteins with common amino- and carboxy-terminal sequences flanking a variable region consisting of different combinations of three short optional elements (Beachy et al. 1985; O'Connor et al. 1988; Kornfeld et al. 1989). UBX Ib contains all three optional elements, and the purified protein binds to clusters of sites downstream of the Ubx and Antp P1 promoters $\left(\mathrm{P}_{\mathrm{Ubx}}\right.$ and $\left.\mathrm{P}_{\mathrm{AntpP} 1}\right)$ and upstream of $\mathrm{P}_{\mathrm{AncpP} 1}$ (Beachy et al. 1988). The common carboxy-terminal sequences of the UBX proteins include the 61-residue homeo domain, a motif shared by Antp, ftz, and eve proteins and many other gene products of the regulatory hierarchy, which functions in DNA binding (for review, see Gehring 1987; Scott et al. 1989). These homeo domains also show more limited sequence similarity to regulatory proteins in other systems, such as the MATal and MAT $\alpha 2$ mating-type control proteins of yeast (Laughon and Scott 1984; Shepherd et al. 1984) and mammalian POU domain proteins (Herr et al. 1988).

UBX and other homeo domain proteins are thought to regulate expression of their targets by binding to these genes and modulating their transcriptional activity; thus, the developmental regulatory hierarchy is commonly viewed as a large cascade of transcription factors (Levine and Hoey 1988; Biggin and Tjian 1989b). Strong support for these ideas has come from transient transfection experiments with cultured $D$. melanogaster 
cells, in which homeo domain protein expression from an introduced gene alters the activity of a target gene promoter fused to a reporter gene such as the chloramphenicol acetyltransferase (CAT) gene (Jaynes and O'Farrell 1988; Driever and Nüsslein-Volhard 1989; Han et al. 1989; Krasnow et al. 1989; Winslow et al. 1989|. In this cotransfection assay, UBX proteins activate and repress transcription from the $U b x$ and Antp Pl promoters, respectively, and high-level activation of the Ubx promoter requires a downstream cluster of UBXbinding sites (Krasnow et al. 1989). In addition, a cluster of consensus UBX-binding sites, comprising repeated TAA trinucleotides (Beachy et al. 1988), is sufficient to confer activation by UBX on a minimal heterologous promoter. UBX proteins can also activate synthetic reporter genes containing UBX-binding sites in heterologous systems such as mammalian cells (Thali et al. 1988) and yeast (Sampson et al. 1989).

To study the biochemical mechanisms of regulation by UBX and other homeo domain proteins and to prove that regulation is direct, we have attempted to reconstruct regulation by UBX in vitro. In this paper we show that a purified UBX protein can stimulate transcription of a synthetic target gene in extracts of cultured D. melanogaster cells and demonstrate the role of promoterregion binding sites in activation. On the basis of the experiments presented here and previous genetic results, it is suggested that the promoter-bound protein activates transcription by interacting with a component of the general transcriptional machinery. Recently, eve protein has also been shown to function in vitro; it acts as a binding site-dependent transcriptional repressor in extracts of $D$. melanogaster embryos (Biggin and Tjian 1989a). These in vitro systems should prove useful for identifying the cellular factors with which UBX and other homeo domain proteins interact and for examining the mechanisms by which they activate and repress target gene transcription.

\section{Results}

Although earlier cell culture cotransfection experiments employed $D$. melanogaster S2 cells (Krasnow et al. 1989|, D. melanogaster Kc cell nuclear extracts were used for the in vitro experiments because they are more active in transcription than S2 cell extracts /C. Parker, pers. comm.l, and $\mathrm{Kc}$ cells are easier and less expensive to maintain in large-scale culture. Although S2 and Kc cell lines are both derived from dissociated embryos, they differ in many characteristics, including morphology, karyotype, optimal culture conditions, and response to ecdysone (for review, see Schneider and Blumenthal 1978; Cherbas and Cherbas 1981). Therefore, as a preliminary step toward the in vitro experiments, we first characterized the transcriptional regulatory effects of a UBX protein in Kc cells by the cotransfection assay.

In Kc cells, expression of a UBX protein repressed $P_{\text {AntpP1 }}$ reporter activity 6- to 24 -fold, whereas the $P_{U b x}$ reporter was stimulated 3- to 10 -fold (Fig. 1A). UBX proteins also activated by 10 - to 100 -fold an alcohol dehy- drogenase gene $(A d h)$ distal promoter $\left(\mathrm{P}_{\mathrm{Adh}}\right)$ construct containing multiple copies of the $(\mathrm{TAA})_{4}$ UBX-binding site consensus sequence (Fig. 1A,B). The $\mathrm{P}_{\text {Adh }}$ sequences in these constructs extend from -33 to +53 , and the binding sites are located 48 bp upstream of the transcription start site. Activation of the Adh promoter depended on the presence of the UBX-binding sites because there was no effect on the construct $\mathrm{pD}-33 \mathrm{CAT}$, which lacks these sites (Fig. 1A), and the stimulatory effect increased with increasing numbers of sites (Fig. 1B). These results are very similar to those obtained in S2 cells (Krasnow et al. 1989), although the magnitude of the UBX regulatory effects in $\mathrm{Kc}$ cells was generally $\sim 50 \%$ less. The relative basal activities of the promoters were also comparable in the two cell lines, with $\mathrm{P}_{\text {AntpP1 }}$ more active than $P_{U b x}$ by 50 - to 200 -fold in Kc cells (Fig. 1A) and 10- to 100-fold in S2 cells (Krasnow et al. 1989). Thus, UBX proteins are transcriptional activators and repressors in Kc cells and S2 cells, and all of the factors necessary to distinguish these two activities, as well as factors required for high basal $P_{\text {AntpPl }}$ activity, are present in the two different cell lines.

We attempted to reconstruct these UBX regulatory activities in vitro using Kc cell nuclear extracts (Parker and Topol 1984). Extracts were programmed with $\mathrm{P}_{\mathrm{Ubx}}$ $\mathrm{P}_{\text {AntpP1}}$, or $\mathrm{P}_{\mathrm{Adh}}$ templates, and transcripts were analyzed by an RNase protection assay or a primer extension assay. Modified $\mathrm{P}_{\text {Adh }}$ templates with downstream deletions were included as internal controls in the reactions. All templates tested were transcriptionally active in the extracts. Initiation occurred at several closely spaced positions in the three promoters (Fig. 2A and data not shown; see also Heberlein et al. 1985; Biggin and Tjian, 1988), and the transcriptional start sites corresponded to those observed in vivo (Laughon et al. 1986; Savakis et al. 1986; Kornfeld et al. 1989). In contrast to the results of the transfection experiments, however, all three promoters had similar basal activities. The relative strength of $\mathrm{P}_{\mathrm{AntpP1}}$ in vitro is less than expected, perhaps because distant upstream enhancer sequences, which confer the high basal activity of $\mathrm{P}_{\text {AntpPl }}$ in cultured cells /E. Parker and M.A. Krasnow, unpubl.), are inactive under our standard in vitro conditions.

When a purified UBX Ib protein produced in Escherichia coli was added to the reactions, there was a 2.5- to 5-fold increase in transcription of $\mathrm{P}_{\mathrm{Adh}}$ templates containing consensus UBX-binding sites (Fig. 2A, lanes 1-4; Fig. 2B, lanes 3-6). Similar levels of activation were observed when a preparation of the UBX protein purified by a different method was tested (see Methods) and when the standard amount of nuclear extract in the reactions was increased or decreased by $50 \%$. More extreme changes in extract concentration reduced the UBX Ib stimulatory effect. The level of activation by UBX Ib under our standard conditions is similar to that observed for several mammalian and D. melanogaster transcription factors in vitro (e.g., OTF-2, Scheidereit et al. 1987; a glucocorticoid receptor derivative, Freedman et al. 1989; zeste protein, Biggin et al. 1988). Indeed, there was an almost identical increase in $\mathrm{P}_{\text {Adh }}$ activity when Adf-1 
A

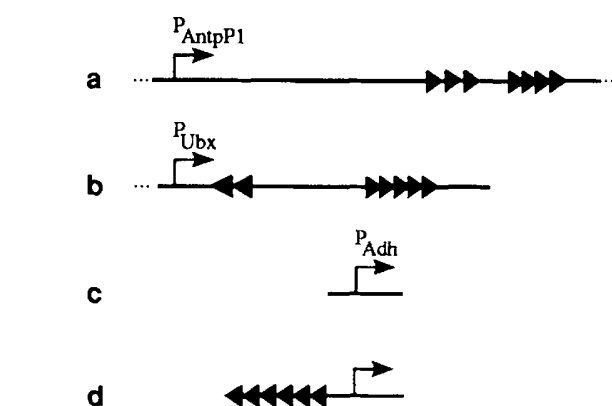

B

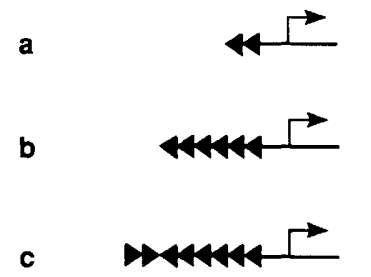

\section{CAT Activity}

$\begin{array}{ccc}\frac{\text { UBX }}{26 \pm 2.6} & \frac{+ \text { UBX }}{2.7 \pm 0.59} & 0.11 \times \\ 0.21 \pm 0.06 & 1.6 \pm 0.16 & 7.8 x \\ <0.01 & <0.01 & (1 x) \\ 0.08 \pm 0.03 & 0.77 \pm 0.20 & 9.2 x\end{array}$

$\begin{array}{lll}0.25 \pm 0.10 & 1.7 \pm 0.60 & 7 x \\ 0.06 \pm 0.05 & 3.2 \pm 0.85 & 54 x \\ 0.03 \pm 0.02 & 3.4 \pm 0.99 & 115 x\end{array}$

$\overline{100 \mathrm{bp}}$

Figure 1. Transcriptional activation and repression by UBX proteins in Kc cells. Cotransfection experiments using $D$. melanogaster $\mathrm{Kc}$ cells were performed with the UBX expression plasmid $\mathrm{pP}_{\mathrm{ac}} \mathrm{UBX} \mathrm{Ib} \mid+\mathrm{UBX}$ ) or the control construct $\mathrm{pP}_{\mathrm{ac}} \mathrm{UBX}_{\mathrm{Ib}}^{\mathrm{s} / \mathrm{B}}$ (- UBX), which does not express UBX proteins, and a reporter plasmid containing the indicated promoter fragment fused to bacterial CAT-coding sequences. Two and one-half days after transfection, CAT activity of the cell extracts was determined (indicated as picomoles of chloramphenicol acetylated per milligram of extract per minute). Values shown are the average and standard deviation of duplicate transfections, and similar results were obtained in two separate experiments. Groups of arrowheads around the Ubx and Antp P1 promoters indicate the position and relative sizes of UBX-binding site clusters (Beachy et al. 1988), and each pair of arrowheads upstream of the $\mathrm{P}_{\text {Adh }}$ constructs represents one copy of the oligonucleotide $5^{\prime}$-CATG $(\text { AAT })_{12}$, which contains consensus UBX-binding sites and is abbreviated U. Arrowheads show the 5' to 3 ' orientation of the TAA elements in the binding sites. Dotted lines indicate that the promoter regions tested extend beyond those shown. $(A)$ The reporter plasmids used were $\mathrm{pP}_{\mathrm{AntpP} 1} \mathrm{CAT}(a) ; \mathrm{pP}_{\mathrm{Ubx}} \mathrm{CAT}(b)$; $\mathrm{pD}-33 \mathrm{CAT}(\mathrm{c})$; and $\mathrm{p}(\mathrm{U}-)_{3} \mathrm{D}-33 \mathrm{CAT}(d)$. Although the activity of $\mathrm{pD}$-33CAT was near background in this experiment, UBX also had no effect in other cotransfection experiments in which the promoter activity was above background. $(B)$ The reporter plasmids used were $\mathrm{p}\left(\mathrm{U}-\mid \mathrm{D}-33 \mathrm{CAT}(a) ; \mathrm{p}(\mathrm{U}-)_{3} \mathrm{D}-33 \mathrm{CAT}(b) ;\right.$ and $\mathrm{p}(\mathrm{U}+)(\mathrm{U}-)_{3} \mathrm{D}-33 \mathrm{CAT}(c)$.

protein-binding sites were present upstream of $\mathrm{P}_{\mathrm{Adh}}$ (Fig. 2B, lanes 7 and 8 ), which we attribute to the Adf-1 transcription factor present in Kc cell nuclear extracts (Heberlein et al. 1985). Activation by UBX Ib was due to increased transcription by RNA polymerase II because both basal and UBX-stimulated transcription were abolished by $\alpha$-amanitin at $1 \mu \mathrm{g} / \mathrm{ml}$ (data not shown), which inhibits $D$. melanogaster RNA polymerase II but not RNA polymerases I or III (Greenleaf et al. 1976).

Transcriptional stimulation of $\mathrm{P}_{\text {Adh }}$ by UBX Ib was dependent on the presence of UBX-binding sites (Fig. 2A). The UBX-binding sites functioned in either orientation (Fig 2C, lanes 1-6), but had to be located near and upstream of the transcription start site. Templates containing binding sites inserted 376 bp upstream of $\mathrm{P}_{\text {Adh }}$ in pD-33CAT (Fig. 2C, lanes 7-9) or 99 bp upstream in $\mathrm{pD}-86 \mathrm{CAT}$, which contains $\mathrm{P}_{\mathrm{Adh}}$ sequences from -86 to +53 , were not stimulated by UBX Ib, nor were templates containing binding sites at downstream positions (Fig 2D). The presence of additional binding sites did not significantly influence the magnitude of the response to UBX Ib (e.g., cf. Fig. $2 \mathrm{~A}$ with $\mathrm{C}$ ), perhaps because the extra sites are too far from the transcription start site. Thus, a UBX protein can activate transcription in vitro, and this effect is mediated through promoter-region binding sites. Stimulation of transcription by the UBX protein did not involve the simple displacement of a repressor in the $\mathrm{Kc}$ cell extracts that binds to the same region, because the presence of the UBX-binding sites did not reduce the basal level activity of $\mathrm{P}_{\text {Adh }}$ (Fig. 2B, lanes 1-4). Furthermore, because transcription of a template containing binding sites fused to $A d h$ promoter sequences between -33 and +3 was stimulated by UBX Ib (Fig. 2E), activation did not involve an effect of bound UBX protein on any elements outside of this minimal promoter.

The dependence of transcriptional activation on UBX Ib concentration is shown in Figure 3. Activation was observed at concentrations as low as $48 \mathrm{~nm}$ and increased up to $192 \mathrm{~nm}$ UBX Ib. In this range, there is an 
A

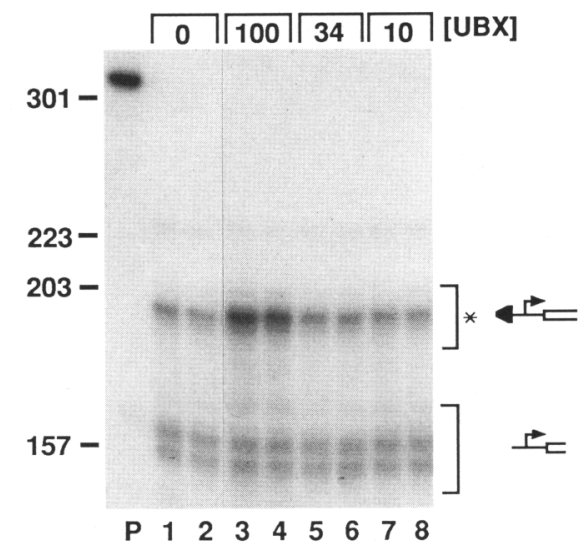

D

B
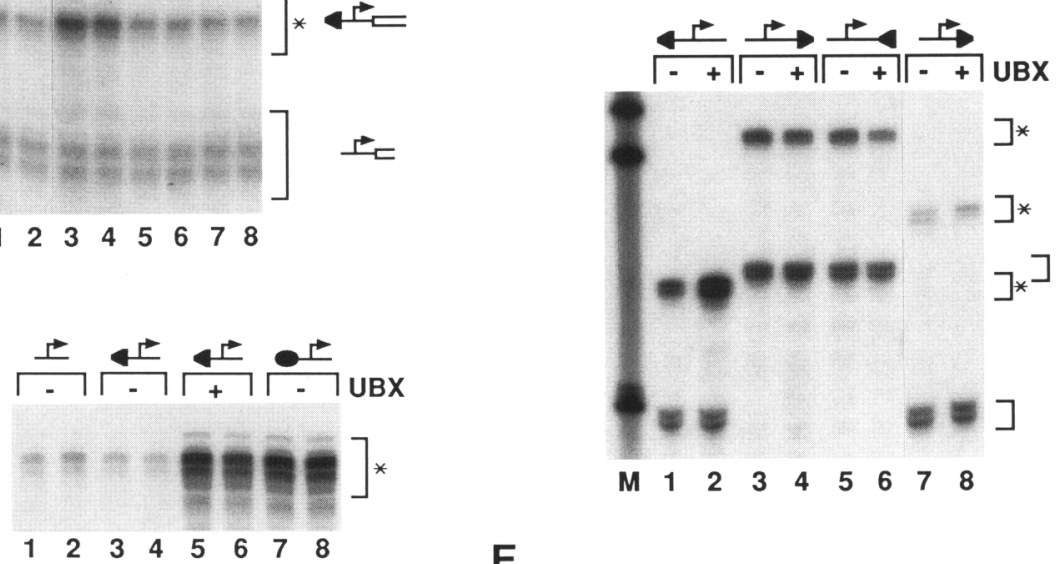

E
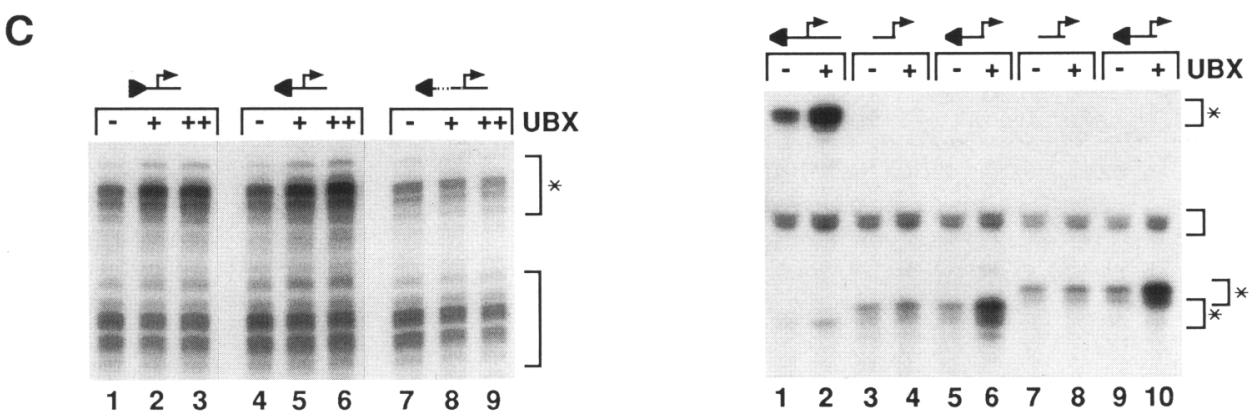

Figure 2. Binding-site-dependent stimulation of transcription by a purified UBX protein in vitro. In vitro transcription reactions were carried out with Kc cell nuclear extracts and contained $\mathrm{P}_{\text {Adh }}$ templates and purified UBX Ib protein, as indicated. Transcripts were analyzed by RNase protection $(A-C)$ or primer extension $(D$ and $E)$, and autoradiographs of the gels are shown. Brackets with asterisks show the protected fragments or the primer extension products derived from transcripts of the experimental templates diagrammed, and the other brackets show the protected fragments or primer extension products from transcripts of a modified $\mathrm{P}_{\text {Adh }}$ internal control plasmid that lacks UBX-binding sites. Arrowheads in the diagrams represent UBX-binding sites. $(A)$ Comparison of templates with and without UBX-binding sites. Reactions were performed in duplicate and contained $p\left(U-\left.\right|_{2} D-33 C A T\right.$, pD-33D (internal control promoter with a downstream deletion), and the indicated concentrations of UBX Ib in nanomolarity. The probe used in the RNase protection analysis was run in lane P. pBR322 DNA digested with HinfI and end-filled with [32P|dATP was run in an adjacent lane; the sizes (in nucleotides) of the fragments are shown at left. (B) Comparison of stimulation by UBX Ib to stimulation by endogenous Adh transcription factors. Duplicate reactions contained no UBX Ib (lanes 1-4, 7, and 8) or $170 \mathrm{nM}$ UBX Ib protein (lanes 5 and 6 ), and the templates in the reactions were pD-33CAT (lanes 1 and 2$)$, p (U-12 D-33CAT (lanes 3-6), and pD-86CAT (lanes 7 and 8 ). pD-86CAT differs from $\mathrm{pD}-33 \mathrm{CAT}$ in that it contains additional $\mathrm{P}_{\text {Adh }}$ sequences from -34 to -86 that include binding sites for the transcription factor Adf-1 (Heberlein et al. 1985; indicated by the solid oval). Note that the presence of UBX-binding sites does not alter basal $P_{A d h}$ activity (lanes 1-4). (C) Effect of binding site orientation and distance from the promoter. Reactions contained no UBX Ib (lanes 1, 4, and 7), $100 \mathrm{nM}$ UBX Ib (lanes 2, 5, and 8) or $200 \mathrm{nM} \mathrm{UBX} \mathrm{Ib} \mathrm{(lanes} \mathrm{3,} \mathrm{6,} \mathrm{and} \mathrm{9).} \mathrm{Templates} \mathrm{in} \mathrm{the} \mathrm{reactions} \mathrm{were} \mathrm{p/U}+$, $_{3} \mathrm{D}-33 \mathrm{CAT}$ (lanes

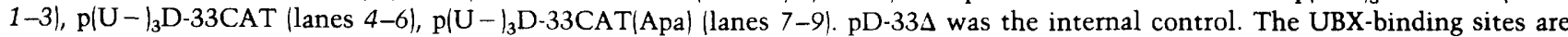
located 47 and $376 \mathrm{bp}$ upstream of the $A d h$ transcription start site in $\mathrm{p}(\mathrm{U}-)_{3} \mathrm{D}-33 \mathrm{CAT}$ and $\mathrm{p}(\mathrm{U}-)_{3} \mathrm{D}-33 \mathrm{CAT}(\mathrm{Apa})$, respectively. $(D)$ Comparison of templates with upstream or downstream binding sites. Reactions contained no UBX Ib $(\operatorname{lanes} 1,3,5$, and 7$)$ or $180 \mathrm{nM}$ $\mathrm{UBX} \mathrm{Ib}$ (lanes 2, 4, 6, and 8), and the templates in the reactions were $\mathrm{p}(\mathrm{U}-)_{2} \mathrm{D}-33 \mathrm{CAT}$ (lanes 1 and 2$), \mathrm{pD}-33 /+52(\mathrm{U}+\mid \mathrm{CAT}(\mathrm{lanes} 3$ and 4), pD-33/ +52(U - KAT (lanes 5 and 6), and pD-33/ +23/U + KAT (lanes 7 and 8). Internal control plasmids were pD-33/ + 23CAT (lanes 1, 2, 7, and 8) and pD-33/ +52CAT (lanes 3-6). HinfI-digested pBR322 DNA markers (lane $M$ ) are 78, 145, and 157 nucleotides. Templates containing binding sites placed at +3 or +7 and templates containing multiple binding site oligonucleotides inserted downstream were not activated by UBX (data not shown). (E) Binding-site-dependent stimulation of a minimal promoter. Reactions contained no UBX Ib (lanes 1, 3, 5, 7, and 9) or 180 nM UBX Ib (lanes 2, 4, 6, 8, and 10), and templates were p(U-) $\left.\right|_{2} \mathrm{D}-33 \mathrm{CAT}$ (lanes 1 and 2), pD-33/ +3CAT (lanes 3 and 4$), \mathrm{p}(\mathrm{U})_{2} \mathrm{D}-33 /+3 \mathrm{CAT}$ (lanes 5 and 6$), \mathrm{pD}-33 /+7 \mathrm{CAT}$ (lanes 7 and 8$)$, and $\mathrm{p}(\mathrm{U})_{3} \mathrm{D}-33 /+7 \mathrm{CAT}(\mathrm{lanes}$ 9 and 10 ). $\mathrm{P}_{\mathrm{Adh}}$ sequences in the templates extend from -33 to +53 (lanes 1 and 2$),+3$ (lanes $3-6$ ), and +7 (lanes $\left.7-10\right) \cdot \mathrm{pD}-33$ / $+23 \mathrm{CAT}$ was the internal control. 


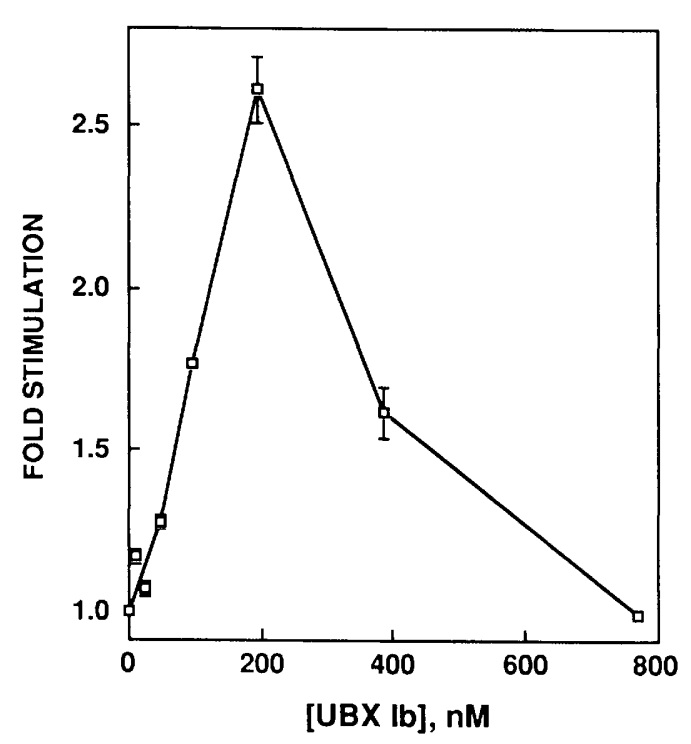

Figure 3. Dependence of transcriptional activation on UBX Ib protein. In vitro transcription reactions containing the template $\mathrm{p} / \mathrm{U}-\left.\right|_{2} \mathrm{D}-33 \mathrm{CAT}$ and $\mathrm{pD}-33 \Delta$ were performed in duplicate with the indicated concentrations of UBX Ib protein. Transcripts were analyzed by RNase protection and quantitated by densitometry of the autoradiographs. The relative amount of $\mathrm{p} / \mathrm{U}-\left.\right|_{2} \mathrm{D}-33 \mathrm{CAT}$ transcription to internal control promoter transcription in each reaction was determined, and fold stimulation was calculated by normalizing these values to the average for reactions without UBX Ib. Error bars indicate standard deviations.

3- to 12-fold molar excess of UBX Ib monomers to promoter region-binding sites. [Although the concentrations of UBX proteins in vivo have not been determined, these in vitro concentrations are within the physiological range of other regulatory proteins, including $\mathrm{ftz}$ protein (Krause et al. 1988)]. At higher UBX Ib concentrations there was a gradual decrease in the level of activation, and at $770 \mathrm{nM}$ UBX Ib, activation was not observed. Similar concentration profiles were obtained with $\mathrm{P}_{\mathrm{Adh}}$ templates containing fewer or additional UBX-binding sites. We do not understand the diminished effect of UBX Ib at high concentrations, but it is not due to a general inhibition of transcription because the activity of the $\mathrm{P}_{\text {Adh }}$ internal control promoter was not affected (data not shown).

We did not detect an effect of UBX Ib on $\mathrm{P}_{\mathrm{Ubx}}$ or $\mathrm{P}_{\mathrm{AntpP1}}$ transcription either under the standard reaction conditions or when the UBX Ib concentration was varied from 40 to $770 \mathrm{nM}$. This may reflect a requirement for upstream or promoter-proximal UBX-binding sites in vitro (see above), because all defined UBX-binding sites in the Antp Pl promoter region lie $>280$ bp away from the start of transcription (Beachy et al. 1988) and because the UBX-binding site cluster shown to be principally responsible for mediating activation of $\mathrm{P}_{\mathrm{Ubx}}$ in transfection experiments is located $210 \mathrm{bp}$ downstream from the transcription start site (Krasnow et al. 1989). We therefore tested a template, $p(\mathrm{UB}+$ ) D-33CAT, in which this naturally occurring binding site cluster from $\mathrm{P}_{\mathrm{Ubx}}$ was in- serted near the $\mathrm{P}_{\text {Adh }}$ transcription start site at the same position in which the UBX-binding site consensus sequence was functional. As shown in Figure 4, the natural binding site cluster mediated activation of $P_{\text {Adh }}$ by UBX Ib and with an efficiency similar to that of the cluster of consensus sites.

\section{Discussion}

We have established an in vitro system to study regulation of target gene expression by purified UBX proteins in extracts of cultured D. melanogaster Kc cells. In this system, UBX Ib proteins activated transcription of synthetic target genes, and activation was mediated through natural or consensus binding sites located close to the promoter. Although recent experiments with cell culture cotransfection assays, including those presented here using Kc cells (Fig. 1), have demonstrated the transcriptional regulatory functions of UBX and other homeo domain proteins and the role of promoter regionbinding sites in regulation, the in vivo effects could conceivably involve the induction of intermediary genes. The in vitro results demonstrate that UBX Ib is an authentic transcription factor and show that at least one UBX regulatory effect is direct. This supports the conclusion that other interactions observed in the cell culture system are also direct, and this conclusion is strengthened by the recent finding that the eve homeo domain protein can repress target gene transcription in a binding site-dependent manner, both in cotransfection experiments and in vitro by use of extracts of $D$. melanogaster embryos (Biggin and Tiian 1989a). Furthermore, four mammalian DNA-binding transcription factors, Oct-1 (Fletcher et al. 1987), Oct-2 (Scheidereit et al. 1987), Pit-1 (Nelson et al. 1988), and HNF-1 (Lichsteiner and Schibler 1989|, show some sequence similarity within their POU homology regions to the D. melanogaster homeo domains (Herr et al 1988; Frain et al. 1989; S. Baumheuter, and G.R. Crabtree, pers. comm.). Thus, an important common function of several, and perhaps many or all, D. melanogaster and mammalian homeo

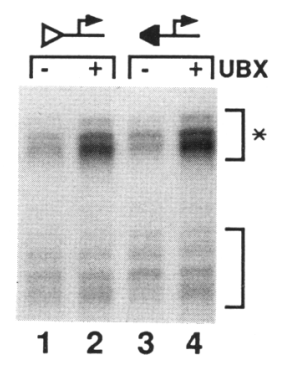

Figure 4. Transcriptional activation mediated through a natural UBX-binding site. In vitro transcription reactions contained $\mathrm{p}(\mathrm{UB}+\mid \mathrm{D}-33 \mathrm{CAT}$ (lanes 1 and 2$)$ or $\mathrm{p}\left(\mathrm{U}-{ }_{2} \mathrm{D}-33 \mathrm{CAT}\right.$

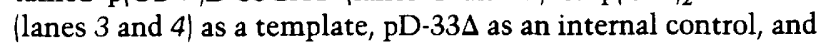
either no UBX Ib (lanes 1 and 3) or $180 \mathrm{nM}$ UBX Ib protein (lanes 2 and 4). Transcripts were analyzed by RNase protection. $\mathrm{p} / \mathrm{UB}+\mid \mathrm{D}-33 \mathrm{CAT}$ contains the 89-bp distal downstream UBXbinding site cluster (open triangle) from the $U b x$ promoter region inserted upstream of $P_{\text {Adh }}$. 
domain proteins is the activation and repression of target gene transcription mediated by protein bound at or near target promoters.

An intriguing aspect of UBX function is its ability to act as an activator or repressor of transcription at different promoters in the same cellular background, both in cultured cells (Fig. 1; Krasnow et al. 1989) and in the developing embryo (Tremml and Beinz 1989). However, it has not yet been possible to reproduce in vitro the observed repression of $\mathrm{P}_{\text {Antp } P_{1}}$ by UBX proteins. We found recently that $\mathrm{UBX}$ represses Antp $\mathrm{Pl}$ transcription in cultured cells by blocking the activity of upstream enhancer sequences that confer a high basal activity on $P_{\text {AntpPl }}$ (E. Parker and M.A. Krasnow, unpubl.). Therefore, to detect UBX repression of this promoter in vitro, it may be necessary to find conditions under which these regulatory elements are active, perhaps by moving them closer to the transcription start site.

An attractive feature of the experimental system described here is its simplicity. It relies only upon ( 1 ) a purified UBX protein, obtainable in milligram amounts from an overproducing $E$. coli strain; (2) a target gene comprising UBX-binding sites linked to a minimal promoter; and (3) nuclear extracts derived from a D. melanogaster cell line that are easy to obtain and lack some of the complexities of whole embryo extracts. Such a streamlined system should be useful for identifying the cellular factors required for UBX to exert its regulatory effects and should provide a means to address questions concerning the mechanism of UBX action.

The results presented here show that UBX Ib does not activate transcription by simply displacing an endogenous repressor, as the presence of UBX-binding sites did not influence the basal transcription rate of the $P_{A d h}$ constructs (Fig. 2B). Rather, we suggest that activation occurs through an interaction between promoter-bound UBX $I b$ and some part of the general transcription machinery, such as RNA polymerase II or TFIID, because UBX Ib stimulated transcription of a target containing UBX-binding sites inserted just upstream of a minimal promoter (Fig. 2E). Such a direct interaction would also explain the partial $U b x$ phenotype observed for certain mutant alleles of the RpII215 gene (e.g., RpII215 Ultrabithorax-like; Mortin and Lefevre 1981; Mortin et al. 1988), which encodes the large subunit of RNA polymerase II (Greenleaf 1983), if these mutations selectively disrupt the proposed interaction. A similar interaction between eve protein and the general transcriptional machinery has been proposed (Biggin and Tjian 1989a), and, if these ideas are correct, it will be important to determine whether the two homeo domain proteins interface differently with the same part of the machinery or whether they interact with two different factors to exert their opposite effects on transcription.

The in vitro system should also facilitate investigations of other aspects of UBX function, such as whether different naturally occurring binding sites influence the regulatory activity of bound UBX Ib, and examinations of which parts of the protein are necessary for transcriptional activation. In addition, it should be possible to de- termine the effect of certain post-translational modifications on UBX regulatory activity, because UBX Ib can be multiply phosphorylated in the nuclear extracts as it is in the developing embryo and tissue culture cells (E.R. Gavis and D.S. Hogness, pers. comm.).

\section{Methods}

Plasmids

The UBX expression plasmid $\mathrm{pP}_{\mathrm{ac}} \mathrm{UBX}$ Ib and the control plasmid $\mathrm{pP}_{\mathrm{ac}} \mathrm{UBX} \mathrm{Ib}^{\mathrm{S} / \mathrm{B}}$, which has a frameshift mutation in $U b x$ codon 8, are described in Krasnow et al. (1989), as are the reporter plasmids $\mathrm{pP}_{\mathrm{Ubx}} \mathrm{CAT}, \mathrm{pP}_{\mathrm{Ubx}} \mathrm{CAT} \Delta 3$, and $\mathrm{pP}_{\mathrm{AntpP}} \mathrm{CAT}$. All reporter plasmids except $\mathrm{pP}_{\mathrm{Antp} \mathrm{P}_{1}} \mathrm{CAT} 18$ contain promoter sequences fused to the CAT-coding sequences in the vector pC4CAT (Thummel et al. 1988). $\mathrm{pP}_{\text {Antpp1 }}$ CAT18, used in some of the in vitro transcription experiments, contains the same $7 \cdot \mathrm{kb}$ HindIII promoter fragment as $\mathrm{pP}_{\mathrm{Antp} P 1} \mathrm{CAT}$ inserted into the end-filled $\mathrm{XbaI}$ site of the vector pCAT18 after end-filling the HindIII overhangs. pCAT 18 contains the $1.6-\mathrm{kb}$ SmaI-SacI CAT-encoding fragment from pC4CAT inserted between the KpnI and SacI sites of pUCl8 after KpnI linker 15'CGGTACCG) addition to the Smal end.

The Adh reporter plasmids $\mathrm{pD}-33 \mathrm{CAT}$ and $\mathrm{pD}-86 \mathrm{CAT}$ contain sequences extending from -33 or -86 to +53 with respect to the $A d h$ distal promoter (Heberlein et al. 1985; B. England and R. Tjian, pers. comm.). The derivative plasmids $\left.\left.\mathrm{p} / \mathrm{U}-\mid \mathrm{D}-33 \mathrm{CAT}, \mathrm{p} / \mathrm{U}-)_{2} \mathrm{D}-33 \mathrm{CAT}, \mathrm{p} / \mathrm{U}-\right)_{3} \mathrm{D}-33 \mathrm{CAT}, \mathrm{p} / \mathrm{U}+\right)_{3} \mathrm{D}-$ $33 \mathrm{CAT}$, and $\mathrm{p}(\mathrm{U}+)(\mathrm{U}-)_{3} \mathrm{D}-33 \mathrm{CAT}$ contain copies of a UBXbinding site consensus oligonucleotide, 5 -CATG(TAA $)_{12}$, inserted 47 bp (for pD-33CAT derivatives) or $99 \mathrm{bp}$ (for $\mathrm{pD}-86 \mathrm{CAT}$ derivatives) upstream of the $A d h$ transcription start site (Krasnow et al. 1989). (U + and $U$ - represent a single copy of the oligonucleotide inserted in the same or the opposite orientation as the promoter, respectively.) $\mathrm{p}(\mathrm{U}-)_{3} \mathrm{D}-33 \mathrm{CAT}$ (Apa) is a related construct that contains the consensus binding sites inserted at the $A p a I$ site 376 bp upstream of the transcription start site (E.E. Saffman and M.A. Krasnow, unpubl.), and $\mathrm{p}(\mathrm{UB}+\mid \mathrm{D}-33 \mathrm{CAT}$ contains the distal downstream binding site cluster at $\mathrm{P}_{\mathrm{Ubx}}$ (Beachy et al. 1988) inserted 48 bp upstream of the transcriptional start (E.E. Saffman and M.A. Krasnow, unpubl.). pD-33 $\Delta$ refers to the internal control templates $\mathrm{pD}-33 \Delta \mathrm{A}$ and $\mathrm{pD}-33 \mathrm{BB}$, which were used interchangeably and are derivatives of $\mathrm{pD}-33 \mathrm{CAT}$ with $\sim 65$-bp deletions in the CAT-coding sequences that were generated by BAL-3l digestion at the $P$ vuII site at +203 . Transcripts from these templates gave an $\sim 33$ nucleotide shorter signal than the undeleted templates in the RNase protection assay.

The $P_{\text {Adh }} 3$ '-deletion plasmids $\mathrm{pD}-33 /+52 \mathrm{CAT}, \mathrm{pD}-33 /$ $+23 \mathrm{CAT}$, pD-33/+7CAT, and $\mathrm{pD}-33 /+3 \mathrm{CAT}$ were constructed with fragments generated by polymerase chain reaction amplification (Saiki et al. 1988) of the pD-33CAT promoter region. The downstream primers $15^{\prime}$-GCTAGCTCGTTAGCCCGTCTGCTGAAC，5'-GCTAGCGACAACTGCACTGAGACAATAAT, 5'-GCTAGCAATAATGCATGACTTGGACC, and 5'-GCTAGCAATGCATGACTTGGACCTTC) contained an Nhel site at their $5^{\prime}$ end and included promoter sequences to $+52,+23,+7$, and $+3 \mathrm{bp}$, respectively. The upstream primer (5'-ATTTGCGAGTACGCAAAGCT) extended into the adjacent polylinker sequences. Amplification products were cleaved at the PstI site of the polylinker and inserted between the PstI and SmaI sites of pC4CAT. pD-33/+52/U-/CAT, $\mathrm{pD}-33 /+52(\mathrm{U}+\mid \mathrm{CAT}$, and $\mathrm{pD}-33 /+23(\mathrm{U}+\mid \mathrm{CAT}$ are derivatives of the $3^{\prime}$-deletion plasmids and contain the UBX consensus binding site oligonucleotide $U$ inserted at the NheI site. 
The sequences of the cloned fragments were confirmed by dideoxynucleotide sequencing. $\mathrm{p}(\mathrm{U})_{2} \mathrm{D}-33 /+3 \mathrm{CAT}$ and $\mathrm{p}(\mathrm{U})_{3} \mathrm{D}$ $33 /+7 \mathrm{CAT}$ are similar derivatives but with $U$ oligonucleotides inserted at the $\mathrm{XbaI}$ site $47 \mathrm{bp}$ upstream of the $\mathrm{P}_{\mathrm{Adh}}$ transcription start site.

Plasmids used to generate antisense probes for RNase protection were constructed in pBluescript $\mathrm{Ml} 3$ (+) vectors (Stratagene). The 265-bp SalI-PvuII fragment from pD-86CAT, containing sequences from -62 to +203 relative to the $A d h$ transcription start site, was inserted between the Sall and SmaI sites of pBluescript $\mathrm{M} 13|+| \mathrm{KS}$ to generate pKS- $\mathrm{P}_{\text {Adh }}$. The plasmid pKS-P $\mathrm{AntpP}_{\text {A } 1}$ contains the BssHII-BamHI Antp Pl promoter fragment $\mid-92$ to +119$)$, derived from $\mathrm{pP}_{\mathrm{AntpP1}} \mathrm{CAT} 18$, inserted between the SmaI and BamHI sites in pBluescript $M 13(+)$ KS after end-filling of the BssHII overhang. The plasmid pSK-P $\mathrm{P}_{\mathrm{Ubx}}$ contains the MluI-SacII $\mathrm{P}_{\mathrm{Ubx}}$ promoter fragment $(-228$ to +110$)$, derived from $p \phi D m 3102$ (R. Saint and D.S. Hogness, pers. comm.l, inserted between the SmaI and SacII sites in pBluescript $M 13|+|$ SK after end-filling of the MluI overhang.

Plasmids were prepared as described (Krasnow et al. 1989).

\section{Transfections and CAT assays}

D. melanogaster Kc cells (Echalier and Ohanessian 1969) were obtained from K. Relloma and D.S. Hogness (Stanford Universityl and were maintained at $10^{6}-10^{7}$ cells $/ \mathrm{ml}$ in Echalier's D-22 medium (Schneider and Blumenthal 1978) without serum at $25^{\circ} \mathrm{C}$. Cells in late log phase $\left(\sim 9 \times 10^{6} \mathrm{cells} / \mathrm{ml}\right)$ were diluted to $2 \times 10^{6}$ cells $/ \mathrm{ml}$, and $5-\mathrm{ml}$ aliquots were plated onto 60 -mm-diameter tissue culture plates. After $24 \mathrm{hr}$ at $25^{\circ} \mathrm{C}, 10$ $\mu \mathrm{g}$ each of supercoiled expression and reporter plasmid DNA was added to each plate as a calcium phosphate coprecipitate, as described (Krasnow et al. 1989). Chloroquine was added to the culture medium to a final concentration of $100 \mu \mathrm{M}$ immediately before adding the precipitate to enhance transfection efficiency (Luthman and Magnusson 1983; Thummel 1989). After $5 \mathrm{hr}$ at $25^{\circ} \mathrm{C}$ the medium was removed, the cells were washed with a HEPES-buffered saline solution (Di Nocera and Dawid 1983), and fresh medium was added. Cells were incubated at $25^{\circ} \mathrm{C}$ for an additional $54-58 \mathrm{hr}$ and then harvested. Extract preparation and CAT assays were performed and quantitated as described in Krasnow et al. (1989), except that the reactions were incubated for up to $4 \mathrm{hr}$. Reactions that extended beyond 2 hr were supplemented with an additional $1.5 \mathrm{~mm}$ acetyl coenzyme A $2 \mathrm{hr}$ after the start of the reaction.

\section{Proteins and cell extracts}

UBX Ib protein was expressed in E. coli and purified as described (Beachy et al. 1988). The same protein was also purified by a different procedure, which will be described in detail elsewhere (J. Lopez, E.R. Gavis, F.B. Johnson, M.A. Krasnow, and D.S. Hogness, unpubl.). Briefly, after cell lysis, polyethylenimine precipitation to remove nucleic acids, and ammonium sulfate fractionation, UBX Ib was chromatographed on a CMSepharose (Pharmacia) column and then a sequence-specific DNA affinity resin. The final preparation was $>95 \%$ pure fulllength UBX Ib, as determined by SDS-PAGE analysis and staining with Coomassie Blue or immunoblotting with the anti-UBX antibody FP3.38 (White and Wilcox 1985). UBX Ib purified by both procedures behaved similarly in the in vitro transcription reactions. UBX Ib protein concentration was determined by the method of Bradford (1976), by using bovine serum albumin as a standard, and is given in UBX Ib monomers.
Nuclear extract used to support transcription was prepared from exponentially growing Kc cells in spinner culture essentially as described by Parker and Topol (1984) and modified by Heberlein et al. (1985). The final protein concentration of the extract was $11 \mathrm{mg} / \mathrm{ml}$, as determined by the method of Bradford (1976) as above.

\section{In vitro transcription and transcript analysis}

Transcription reactions were performed essentially as described by Parker and Topol (1984). Standard reactions were carried out in a final volume of $25 \mu \mathrm{l}$ and contained $37 \mathrm{mM}$ HEPES-Cl $/ \mathrm{pH}$ 7.6), $6 \mathrm{~mm}$ Tris- $\mathrm{Cl}(\mathrm{pH} 7.5), 6.25 \mathrm{~mm} \mathrm{MgCl}_{2}, 0.8 \mathrm{~mm}$ DTT, 0.2 $\mathrm{mM}$ EDTA, 7.5\% (vol/vol) glycerol, $20 \mathrm{mM} \mathrm{KCl,} 50 \mathrm{mM} \mathrm{NaCl}$, $500 \mu \mathrm{M}$ NTPs, $0.8 \mu \mathrm{m} / \mu \mathrm{l}$ RNasin (Promega), supercoiled plasmid template DNA at $10 \mu \mathrm{g} / \mathrm{ml}$, and an internal control promoter plasmid at $10 \mu \mathrm{g} / \mathrm{ml}$. For experiments with $P_{\mathrm{Ubx}}$ and $\mathrm{P}_{\text {AntpP1 }}$ templates $\left(\mathrm{pP}_{\mathrm{Ubx}} \mathrm{CAT} \Delta 3\right.$ and $\left.\mathrm{pP}_{\text {Antp PI }} \mathrm{CAT} 18\right)$, the concentration of the $\mathrm{pD}-33 \Delta$ internal control was $3 \mu \mathrm{g} / \mathrm{ml}$. UBX Ib protein was added to the reaction mixture and incubated at $0^{\circ} \mathrm{C}$ for 15-20 min before the addition of $55 \mu \mathrm{g}$ of nuclear extract. After $30 \mathrm{~min}$ at $22^{\circ} \mathrm{C}$, reactions were stopped by the addition of $100 \mu \mathrm{l}$ of termination buffer [1\% Sarkosyl, $10 \mathrm{mM}$ EDTA, 100 $\mathrm{mM}$ Tris-Cl $(\mathrm{pH} 8.0) 100 \mathrm{mM} \mathrm{NaCl}$, and $0.1 \mathrm{mg} / \mathrm{ml}$ yeast tRNA]l, and the reaction products were extracted three times with PCI [phenol/chloroform/isoamyl alcohol $(25: 24: 1)]$ and ethanol precipitated. Products to be analyzed by RNase protection were resuspended in $45 \mu l \mathrm{RQ} 1$ buffer $[40 \mathrm{~mm}$ Tris- $\mathrm{Cl}$ (pH $7.9 \mid, 10 \mathrm{mM} \mathrm{NaCl}$, and $6 \mathrm{mM} \mathrm{MgCl}$ ], treated with 2 units of RQ1 DNase (Promega) for $20 \mathrm{~min}$ at $37^{\circ} \mathrm{C}, \mathrm{PCI}$-extracted, and precipitated with ethanol.

RNase protection analysis of the reaction products was performed as described by Gilman (1987). Antisense probes labeled with ${ }^{32} \mathrm{P}$ were synthesized by using T7 RNA polymerase, [32P]UTP $(650 \mathrm{Ci} / \mathrm{mmole})$, and linearized DNA templates (pKS$\mathrm{P}_{\text {Adh }}$ cleaved with SalI, pKS- $\mathrm{P}_{\text {Antpp } 1}$ cleaved with EcoRI, or pSK$\mathrm{P}_{\mathrm{Ubx}}$ cleaved with SacI and treated with T4 DNA polymerase to remove the $3^{\prime}$ overhang). Probe $\left(5-7 \times 10^{5} \mathrm{cpm}\right)$ was hybridized to the in vitro transcription reaction products for $8-16 \mathrm{hr}$ at $48^{\circ} \mathrm{C}$, treated with RNases $\mathrm{A}$ and $\mathrm{Tl}$ for $1 \mathrm{hr}$ at $30^{\circ} \mathrm{C}$, and analyzed by electrophoresis through $6 \%$ polyacrylamide gels containing $7.8 \mathrm{M}$ urea. Autoradiographs of the gels were quantitated by scanning densitometry.

Primer extension analysis was performed essentially as described (Jones et al. 1985). The CAT gene primer (Krasnow et al. 1989|, complementary to nucleotides +73 to +97 of transcripts from pD-33CAT, was ${ }^{32} \mathrm{P}$-labeled at its 5 ' end by use of T4 polynucleotide kinase. Primer ( $50 \mathrm{fmoles}$ ) was added to the in vitro transcription reaction products, and nucleic acids were concentrated by ethanol precipitation. Primer annealing was carried out at $42^{\circ} \mathrm{C}$ in $10 \mu l$ of annealing buffer $250 \mathrm{mM} \mathrm{KCl}, 2$ $\mathrm{mm}$ Tris- $\mathrm{Cl}$ (pH 8.0), and $0.2 \mathrm{~mm}$ EDTA) for $3 \mathrm{hr}$. Primer extension was initiated by the addition of $24 \mu \mathrm{l}$ of PE buffer $[40 \mathrm{mM}$ Tris-Cl (pH 8.7), $10 \mathrm{~mm} \mathrm{MgCl}_{2}, 1 \mathrm{~mm}$ dNTPs, $5 \mathrm{~mm}$ DTT, 100 $\mu \mathrm{g} / \mathrm{ml}$ actinomycin $\mathrm{D}$, and $0.4 \mu \mathrm{m} / \mu \mathrm{l}$ RNasin] and 10 units AMV reverse transcriptase, and the reactions were incubated at $40^{\circ} \mathrm{C}$ for $60 \mathrm{~min}$. The extension products were analyzed as described above for the RNase protection products.

\section{Acknowledgments}

We thank Emma Saffman for stimulating discussions and for providing plasmids and Javier Lopez and Elizabeth Gavis for advice on the UBX protein purification. We also thank Paul Mitsis, Kerry Kornfeld, Elizabeth Gavis, and the members of this laboratory for their comments on the manuscript. F.B.J. 
was supported by the Medical Scientist Training Program of the National Institutes of Health (NIH) and M.A.K. is a Lucille P. Markey Scholar in Biomedical Science. This work was supported by grants from the Lucille P. Markey Charitable Trust and the NIH to M.A.K.

\section{References}

Akam, M. 1987. The molecular basis for metameric pattern in the Drosophila embryo. Development 101: 1-22.

Beachy, P.A., S.L. Helfand, and D.S. Hogness. 1985. Segmental distribution of bithorax proteins during Drosophila development. Nature 313: 545-551.

Beachy, P.A., M.A. Krasnow, E.R. Gavis, and D.S. Hogness. 1988. An Ultrabithorax protein binds sequences near its own and the Antennapedia P1 promoters. Cell 55: 10691081 .

Bienz, M. and G. Tremml. 1988. Domain of Ultrabithorax expression in Drosophila visceral mesoderm from autoregulation and exclusion. Nature 333: $576-578$

Biggin, M.D. and R. Tjian. 1988. Transcription factors that activate the Ultrabithorax promoter in developmentally staged extracts. Cell 53: 699-711.

- 1989a. A purified Drosophila homeo domain protein represses transcription in vitro. Cell 58: $433-440$.

- 1989b. Transcription factors and the control of Drosophila development. Trends Genet. 5: 377-383.

Biggin, M.D., S. Bickel, M. Benson, V. Pirrotta, and R. Tjian 1988. zeste encodes a sequence-specific transcription factor that activates the Ultrabithorax promoter in vitro. Cell 53: $713-722$.

Bradford, M. 1976. A rapid and sensitive method for the quantitation of microgram quantities of protein utilizing the principle of protein dye binding. Anal. Biochem. 72: 248-254.

Carroll, S.B., R.A. Laymon, M.A. McCutcheon, P.D. Riley, and M.P. Scott. 1986. The localization and regulation of Antennapedia protein expression in Drosophila embryos. Cell 47: $113-122$.

Cherbas, L. and P. Cherbas. 1981. The effects of ecdysteroid hormones on Drosophila melanogaster cell lines. In $\mathrm{Ad}$ vances in cell culture (ed. K. Maramorosch), vol. 1, pp. 91-124. Academic Press, New York.

Di Nocera, P.P. and I.B. Dawid. 1983. Transient expression of genes introduced into cultured cells of Drosophila. Proc. Natl. Acad. Sci. 80: 7095-7098.

Driever, W. and C. Nüsslein-Volhard. 1989. The bicoid protein is a positive regulator of hunchback transcription in the early Drosophila embryo. Nature 337: 138-143.

Duncan, I. 1987. The bithorax complex. Annu. Rev. Genet. 21: $285-319$.

Echalier, G. and A. Ohanessian. 1969. Isolement, en cultures in vitro de lignees cellulaires diploides de Drosophila melanogaster. CR Acad. Sci. Ser. B 268: 1771-1773.

Fletcher, C., N. Heintz, and R.G. Roeder. 1987. Purification and characterization of OTF-1, a transcription factor regulating cell cycle expression of a human histone $\mathrm{H} 2 \mathrm{~b}$ gene. Cell 51: 773-781.

Frain, M., G. Swart, P. Monaci, A. Nicosia, S. Stampfli, R. Frank, and R. Cortese. 1989. The liver-specific transcription factor LF-B1 contains a highly diverged homeobox DNA binding domain. Cell 59: 145-157.

Freedman, L.P., S.K. Yoshinaga, J.N. Vanderbilt, and K.R. Yamamoto. 1989. In vitro transcription enhancement by purified derivatives of the glucocorticoid receptor. Science 245: $298-301$.
Garcia-Bellido, A. 1975. Genetic control of wing disc development in Drosophila. In Cell patterning. Ciba Found. Symp. 29: 161-182. Elsevier, New York.

Gehring, W.J. 1987. Homeo boxes in the study of development Science 236: 1245-1252.

Gilman, M. 1987. Ribonuclease protection assay. In Current protocols (ed. F.M. Ausubel, R. Brent, R.E. Kingston, D.D. Moore, J.G. Seidman, J.A. Smith, and K. Struhl.), Unit 4.7. Greene Publishing Associates and Wiley-Interscience, New York.

Greenleaf, A.L. 1983. Amanitin-resistant RNA polymerase II mutations are in the enzyme's largest subunit. $J$. Biol. Chem. 258: 13403-13406.

Greenleaf, A.L., A. Krämer, and E.K.F. Bautz. 1976. DNA-dependent RNA polymerases from Drosophila melanogaster larvae. In RNA polymerase (ed. R. Losich and M. Chamberlin), pp. 793-801. Cold Spring Harbor Laboratory Press, Cold Spring Harbor, New York.

Hafen, E., M. Levine, and W.J. Gehring. 1984. Regulation of Antennapedia transcript distribution by the bithorax complex in Drosophila. Nature 307: 287-289.

Han, K., M.S. Levine, and J.L. Manley. 1989. Synergistic activation and repression of transcription by Drosophila homeobox proteins. Cell 56: 573-583.

Heberlein, U., B. England, and R. Tjian. 1985. Characterization of Drosophila transcription factors that activate the tandem promoters of the alcohol dehydrogenase gene. Cell 41: 965 977.

Herr, W., R.A. Sturm, R.G. Clerc, L.M. Corcoran, D. Baltimore, P.A. Sharp, H.A. Ingraham, M.G. Rosenfeld, M. Finney, G. Ruvkun, and H.R. Horvitz. 1988. The POU domain: A large conserved region in the mamalian pit-1, oct-1, oct-2, and Caenorhabditis elegans unc-86 gene products. Genes Dev. 2: $1513-1516$

Ingham, P.W. 1988. The molecular genetics of embryonic pattern formation in Drosophila. Nature 335: 25-34.

Jaynes, J.B., and P.H. O'Farrell. 1988. Activation and repression of transcription by homeodomain-containing proteins that bind a common site. Nature 336: 744-749.

Jones, K.A., K.R. Yamamoto, and R. Tjian. 1985. Two distinct transcription factors bind to the HSV thymidine kinase promoter in vitro. Cell 42: 559-572.

Kaufman, T., M.A. Seeger, and G. Olsen. 1990. Molecular and genetic organization of the Antennapedia gene complex of Drosophila melanogaster. In Advances in genetics. (ed. T.R.F. Wright), vol. 27, pp. 309-361. Academic Press, San Diego.

Kornfeld, K., R.B. Saint, P.A. Beachy, P.J. Harte, D.A. Peattie, and D.S. Hogness. 1989. Structure and expression of a family of Ultrabithorax mRNAs generated by alternative splicing and polyadenylation in Drosophila. Genes Dev. 3: 243-258.

Krasnow, M.A., E.E. Saffman, K. Kornfeld, and D.S. Hogness. 1989. Transcriptional activation and repression by Ultrabithorax proteins in cultured Drosophila cells. Cell 57: $1031-1043$.

Krause, H. M., R. Klemenz, and W. Gehring. 1988. Expression, modification, and localization of the fushi tarazu protein in Drosophila embryos. Genes Dev. 2: 1021-1036.

Laughon, A., and M.P. Scott. 1984. Sequence of a Drosophila segmentation gene: Protein structure homology with DNAbinding proteins. Nature 310: 25-31.

Laughon, A., A.M. Boulet, J.R.J. Bermingham, R.A. Laymon, and M.P. Scott. 1986. Structures of transcripts from the homeotic Antennapedia gene of Drosophila melanogaster: Two promoters control the major protein-coding region. Mol. Cell. Biol. 6: 4676-4689. 
Levine, M. and T. Hoey. 1988. Homeobox proteins as sequencespecific transcription factors. Cell 55: 537-540.

Lewis, E.B. 1964. Genetic control and regulation of developmental pathways. In The role of chromosomes in development (ed. M. Locke), pp. 231-252. Academic Press, New York.

- 1978. A gene complex controlling segmentation in Drosophila. Nature 276: 565-570.

Lichsteiner, S. and U. Schibler. 1989. A glycosylated liver-specific transcription factor stimulates transcription of the albumin gene. Cell 57: 1179-1187.

Luthman, H. and G. Magnusson. 1983. High efficiency polyoma DNA transfection of chloroquine treated cells. Nucleic Acids Res. 11: 1295-1308.

Maniatis, T., E.F. Fritsch, and J. Sambrook. 1982. Molecular cloning: A laboratory manual. Cold Spring Harbor Laboratory Press, Cold Spring Harbor, New York.

Mortin, M.A., and G. Lefevre. 1981. An RNA polymerase II mutation in Drosophila melanogaster that mimics Ultrabithorax. Chromosoma 82: 237-247.

Mortin, M.A., W.J. Kim, and J. Huang. 1988. Antagonistic interactions between alleles of the RPII215 locus in Drosophila melanogaster. Genetics 119: 863-873.

Müller, M.M., S. Ruppert, W. Schaffner, and P. Matthias. 1988. A cloned octamer transcription factor stimulates transcription from lymphoid-specific promoters in non-B cells. $\mathrm{Na}$ ture 336: $544-557$.

Nelson, C., V.R. Albert, H.P. Elsholtz, L.I.-W. Lu., and M.G. Rosenfeld. 1988. Activation of cell-specific expression of rat growth hormone and prolactin genes by a common transcription factor. Science 239: 1400-1405.

O'Connor, M.B., R. Binari, K.A. Perkins, and W. Bender. 1988. Alternative RNA products from the Ultrabithorax domain of the bithorax complex. EMBO /. 7: 435-445.

Parker, C.S. and J. Topol. 1984. A Drosophila RNA polymerase II transcription factor contains a promoter-region-specific DNA-binding activity. Cell 26: 357-369.

Saiki, R.K., D.H. Gelfand, S. Stoffel, S.J. Scharf, R. Higuchi, G.T. Horn, K.B. Mullis, and H.A. Erlich. 1988. Primer-directed enzymatic amplification of DNA with a thermostable DNA polymerase. Science 239: 487-491.

Sampson, M-L., L. Jackson-Grusby, and R. Brent. 1989. Gene activation and DNA binding by Drosophila $U b x$ and $a b d-A$ proteins. Cell 57: 1045-1052.

Savakis, C., M. Ashburner, and J.H. Willis. 1986. The expression of the gene coding for alcohol dehydrogenase during the development of Drosophila melanogaster. Dev. Biol. 114: 194-207.

Scheidereit, C., A. Heguy, and R.G. Roeder. 1987. Identification and purification of a human lymphoid-specific octamerbinding protein (OTF-2) that activates transcription of an immunoglobulin promoter in vitro. Cell 51: 783-793.

Schneider, I. and A.B. Blumenthal, 1978. Drosophila cell and tissue culture. In Genetics and biology of Drosophila (ed. M. Ashburner and T.R.F. Wright), vol. 2A, pp. 265-315. Academic Press, New York.

Scott, M.P. and S.B. Carroll. 1987. The segmentation and homeotic gene network in early Drosophila development. Cell 51: $689-698$.

Scott, M.P., J.W. Tamkun, and G.W. Hartzell. 1989. The structure and function of the homeo domain. B.B.A. Rev. Cancer 989: 25-48.

Sheperd, J.C.W., W. McGinnis, A.E. Carrasco, E.M. DeRobertis, and W.J. Gehring. 1984. Fly and frog homeo domains show homologies with yeast mating type regulatory proteins. $\mathrm{Na}$ ture 310: $70-71$.
Thali, M., M.M. Muller, M. DeLorenzi, P. Matthias, and M. Bienz. 1988. Drosophila homoeotic genes encode transcriptional activators similar to mammalian OTF-2. Nature 336: $598-601$.

Thummel, C.S. 1989. The Drosophila E74 promoter contains essential sequences downstream from the start site of transcription. Genes Dev. 3: 782-792.

Thummel, C.S., A.M. Boulet, and H.D. Lipshitz. 1988. Vectors for Drosophila $\mathrm{P}$ element-mediated transformation and tissue culture transfection. Gene 74: 445-456.

Tremml, G. and M. Bienz. 1989. Homeotic gene expression in the visceral mesoderm of Drosophila embryos. EMBO $I$. 8: $2677-2685$.

Wakimoto, B.T. and T.C. Kaufman. 1981. Analysis of larval segmentation in lethal genotypes associated with the $A n$ tennapedia gene complex in Drosophila melanogaster. Dev. Biol. 81: $51-64$.

White, R.A.H. and M. Wilcox. 1985. Distribution of Ultrabithorax proteins in Drosophila. EMBO /. 4: 2035-2043.

Winslow, G.M., S. Hayshi, M.A. Krasnow, D.S. Hogness, and M.P. Scott. 1989. Gene activation by the Antennapedia and fushi tarazu proteins in cultured Drosophila cells. Cell 57: $1017-1030$.

Wirz, I., L.I. Fessler, and W.J. Gehring. 1986. Localization of the Antennapedia protein in Drosophila embryos and imaginal discs. EMBO /. 5: 3327-3334. 


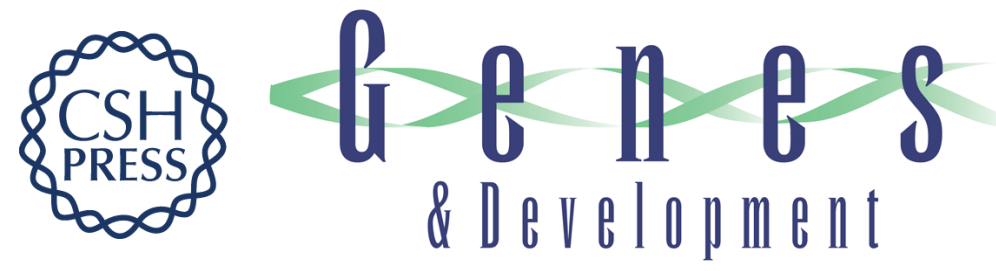

\section{Stimulation of transcription by an Ultrabithorax protein in vitro.}

F B Johnson and M A Krasnow

Genes Dev. 1990, 4:

Access the most recent version at doi:10.1101/gad.4.6.1044 $\begin{array}{ll}\text { References } & \begin{array}{l}\text { This article cites } 56 \text { articles, } 13 \text { of which can be accessed free at: } \\ \text { http://genesdev.cshlp.org/content/4/6/1044.full.html\#ref-list-1 }\end{array}\end{array}$

License

Email Alerting

Receive free email alerts when new articles cite this article - sign up in the box at the top Service right corner of the article or click here.

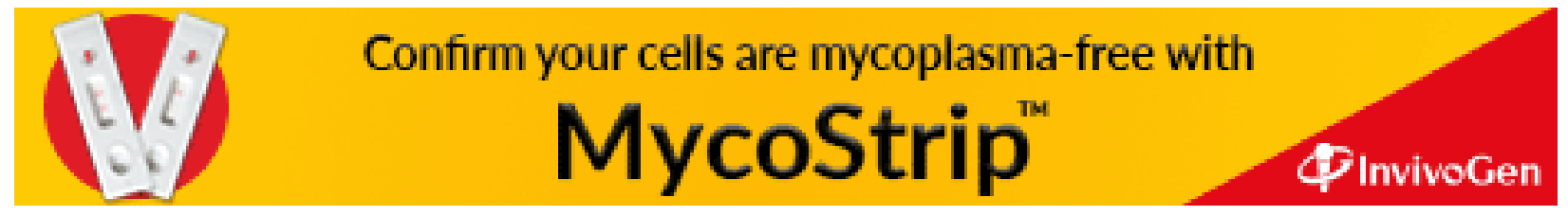

